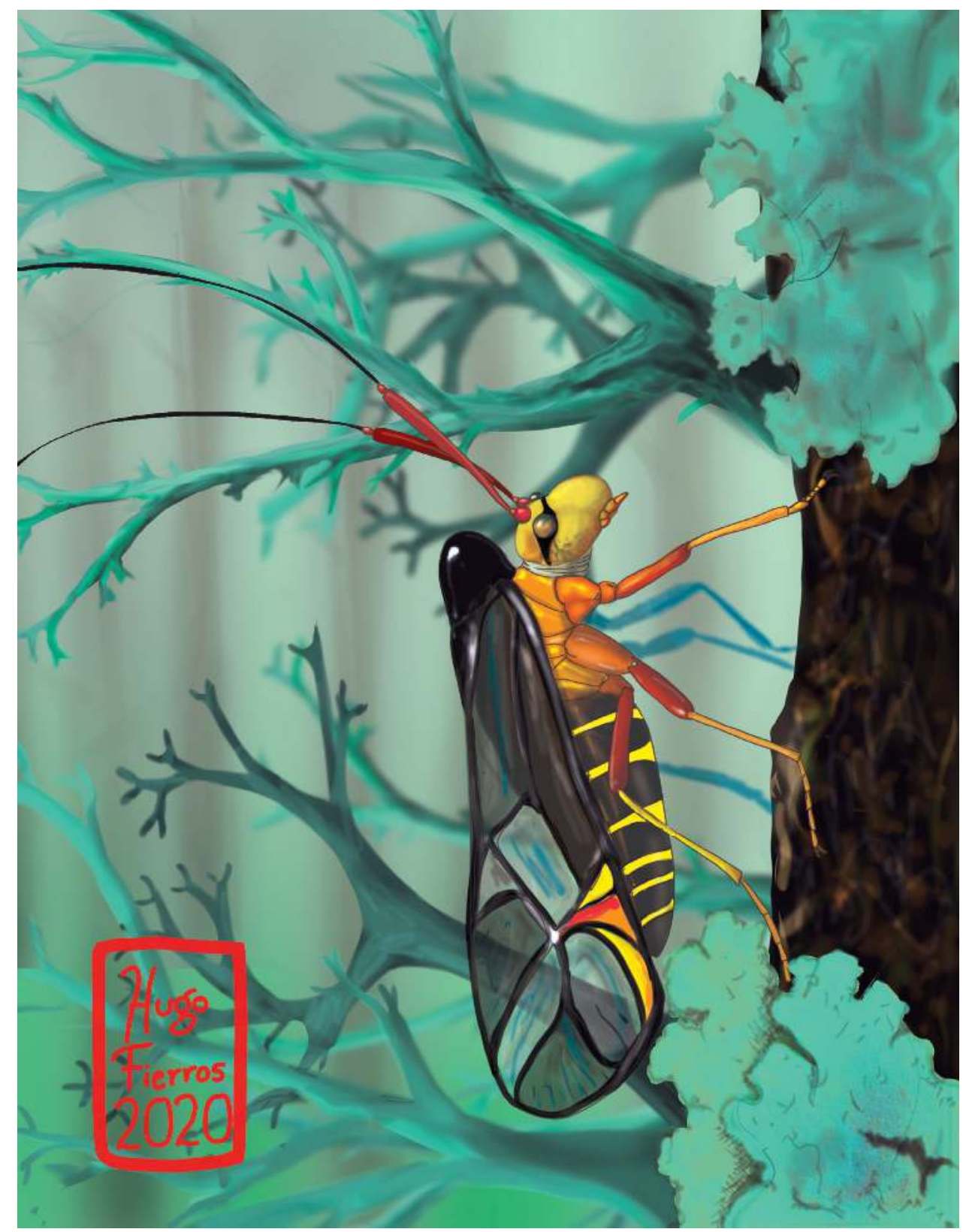

Dugesiana, Año 27, No. 2, julio 2020-diciembre 2020 segundo semestre de 2020), es una publicación semestral, editada por la Universidad de Guadalajara, a través del Centro de Estudios en Zoología, por el Centro Universitario de Ciencias Biológicas y Agropecuarias. Camino Ramón Padilla Sánchez \# 2100, Nextipac, Zapopan, Jalisco, Tel. 37771150 ext. 33218, http://148.202.248.171/dugesiana/index.php/DUG/index, glenusmx@gmail.com. Editor responsable: José Luis Navarrete-Heredia. Reserva de Derechos al Uso Exclusivo 04-2009-062310115100203, ISSN: 2007-9133, otorgados por el Instituto Nacional del Derecho de Autor. Responsable de la última actualización de este número: José Luis Navarrete-Heredia, Editor y Ana Laura González-Hernández, Asistente Editorial. Fecha de la última modificación 1 de julio 2020, con un tiraje de un ejemplar.

Las opiniones expresadas por los autores no necesariamente reflejan la postura del editor de la publicación.

Queda estrictamente prohibida la reproducción total o parcial de los contenidos e imágenes de la publicación sin previa autorización de la Universidad de Guadalajara. 


\title{
New species of Neurostigma Enderlein, 1901 (Insecta: Psocodea: Epipsocidae) from Colombia
}

\author{
Nueva especie de Neurostigma Enderlein, 1901 (Insecta: Psocodea: Epipsocidae) de Colombia
}

\author{
Julián Alexander Mendivil Nieto ${ }^{1,2 *}$, Ranulfo González Obando ${ }^{1,3}$ y Nancy Carrejo Gironza ${ }^{1,4}$ \\ ${ }^{1}$ Departamento de Biología, Facultad de Ciencias Naturales y Exactas, Universidad del Valle, Santiago de Cali, \\ COLOMBIA.E-mail: ${ }^{2}$ chalcidoidea88@gmail.com; ${ }^{3}$ ranulfo.gonzalez@correounivalle.edu.co; ${ }^{4}$ nancy.carrejo@ \\ correounivalle.edu.co
}

\begin{abstract}
In a review of the Epipsocidae from two Natural Parks in the Colombian amazon, two species of Neurostigma were found, one of which corresponds to $N$. xanthopterum, a new record for the country; the other being a new species which is here described and illustrated. A key for identification of the described species (males) is also presented.

Key words: Biodiversity, Epipsocetae, Neotropic, Taxonomy.
\end{abstract}

\section{RESUMEN}

En una revisión de los Epipsocidae de dos Parques Natural de la amazonia colombiana, se encontraron dos especies de Neurostigma, una de las cuales corresponde a $N$. xanthopterum, un nuevo registro para el país; la otra es una especie nueva, la cual es aquí descrita e ilustrada. Una clave para la identificación de las especies (machos) descritas también es presentada.

Palabras clave: Biodiversidad, Epipsocetae, Neotrópico, Taxonomía.

Neurostigma Enderlein, 1901, is a small genus of Epipsocidae that currently has only eight known species and for which there had been not new descriptions for over 20 years. This genus was considered by Eertmoed (1973) as part of the monogeneric family Neurostigmidae (= Neurostigmatidae, from Mockford 1998), but in a phylogenetic analysis performed by Casasola-Gonzalez (2006) it was shown that it is closely related to the Epipsocidae genera given that several synapomorphies are shared: legs with two tarsomeres and forewing with a single anal vein. Of the eight known species, New (1980) described four, with distribution in Brazil. The other four were described by Badonnel (1986), Enderlein (1901), Mockford (1991) and Roesler (1940). For Colombia, Badonnel (1986) described the species $N$. furcivenula based on a female collected in the Magdalena department and is until now the only species of this genus recorded for the country. In recent review of specimens collected by the Alexander von Humboldt Institute $(\mathrm{IAvH})$ in the Natural Park Mosiro-Itajura (Colombia: Vaupés) and National Natural Park Amacayacu (Colombia), five male specimens of Neurostigma were found, two of them corresponding to a known species and the other three considered as a new species which is here described and illustrated.

\section{MATERIAL AND METHODS}

The specimens were collected as part of the "Insect Diversity of Colombia" project developed by the Alexander von Humboldt Biological Resources Research Institute $(\mathrm{IAvH})$ and the Unidad Administrativa Especial de Parques
Nacionales Naturales (UESPPN) (Special Administrative Unit of National Natural Parks). Five male specimens were available for study, which were dissected in $80 \%$ ethanol, followed by mounting their parts on slides in Canada balsam following standard procedures (González et al. 2011). Color was recorded from whole specimens, observed under a dissecting microscope illuminated with cold white light at 50x. Measurements (given in $\mu \mathrm{m}$ ) of parts on the slides (head, right wings and legs and genitalia), were measured with a micrometer, mounted on a Nikon Eclipse Ci microscope. Abbreviations for the measured parts are as follows: $\mathrm{H}$ : head median length (in dorsal view); MxW: maximum width of head capsule; Mx2, Mx4: length of second and fourth segment of right maxillary palpus, f1...fn: lengths of flagellomeres $1 . . . \mathrm{n}$ of right antenna, IO, D and d, respectively: minimum distance between compound eyes, antero-posterior diameter and transverse diameter of right compound eye, all in dorsal view of head; FW and HW: lengths of right fore- and hind- wings, L: forewing length; W: forewing width; lp: pterostigma length; wp: pterostigma width; 1: hindwing length; w: hindwing width; al: areola postica length; ah: areola postica height; F, T, t1-t2: lengths of femur, tibia and tarsomeres 1-2 of right hind leg, ctt1: number of ctenidiobothria on $\mathrm{t} 1 \mathrm{of}$ right hind leg. Additionally, head and wings ratios were measured: $\mathrm{H} / \mathrm{MxW}$; $\mathrm{PO}: \mathrm{d} / \mathrm{D} ; \mathrm{IO} / \mathrm{d}$; L/W; 1/w; lp/wp; al/ah (González et al. 2011). The illustrations were made based on digital photographs, taken with a Canon T5i camera and Helicon Focus program, and later processed in Clip Studio Paint vector graphics editor program. The scales are given in $\mathrm{mm}$. The specimens are provi- 
sionally deposited in the Entomological Museum, Universidad Del Valle, Santiago de Cali, Colombia (MUSENUV).

\section{RESULTS}

Neurostigma garcialdretei $\mathrm{n}$. sp. (Male)

(Figures 1-6)

http://zoobank.org/EFE663DB-6436-4DF4-80DF-AE2B99F79AF4

Diagnosis. Belonging to a group of species whose areola postica is not fused to vein M. By characters of his forewing and phallosome is similar to $N$. radiatum Mockford, 1991, but unlike this presents the radular sclerite of phallosome with pointed spines directed antero-mesally, long spicules on external margin and dense field of short spines and spicules latero-posteriorly, aedeagal arc with internal apical edge not angled (Fig. 6). It also differs from this in details of the pterostigmal crossveins.

Color (in $80 \%$ ethanol). Body cream, with brown spots. Head cream (Fig. 3) with a light dark brown spot from the antennal socket to the lower margin of the compound eye, going up the posterior edge of the eye to its upper edge; a second brown band goes from the antennal socket to the top of the gena; vertex, front, posclypeus, gena and postgena cream. Compound eyes black, ocelli hyaline with ochre centripetal crescents; anteclypeus cream; labrum cream; labral sclerites light brown. Antenna light brown. Maxillary palps cream, with dark brown dorsal line from base to apex. Tergal lobes of mesothorax cream, posterior edge brown; tergal lobes of metathorax brown and cream; thoracic pleura cream. Legs: coxae cream, with apice light black; trochanters cream; femora cream, with circular black spots; tibiae cream; tarsi light brown. Forewing hyaline (Fig. 1), areola postica with light brown spot like a halo around it; pterostigma with veins dark brown; nodulus black; veins pale brown. Hindwing hyaline, with veins pale brown. Abdomen: tergum with black bands, sternum cream. Clunium pale brown, darker medially. Hypandrium missing in holotype; in paratypes is light brown. Phallosome dark brown, radula with dark brown teeth. Epiproct and paraprocts light brown.

Morphology. Head with abundant macrosetae, mainly on the vertex (Fig. 3): H/MxW: $1.45 ; \mathrm{H} / \mathrm{d}: 5.06 ; \mathrm{IO} /$ $\mathrm{MxW}: 0.83$. Vertex convex, clearly above the upper border of the compound eyes. Outer cusp of lacinial apex broad, with six denticles. Labrum with five distal sensilla: a central placoid, flanked by a tricoid-placoid pair. Mx4/Mx2: 1.14. Forewings (Fig. 1): L/W: 2.54. Pterostigma elongated: 1p/ wp: 3.52, wider medially, with five crossveins. Rs before transversal $\mathrm{r}-\mathrm{m}$ straight basally; $\mathrm{M}$ three-branched; concave after of transversal $\mathrm{r}-\mathrm{m}$. Areola postica low, rounded apically: al/ah: 1.88 , separated from vein $\mathrm{CuA}_{2}$ by about half its own length; R2+3 and R4+5 sinuous. Hindwings elongated (Fig. 2): 1/w: 3.18; M simple, unbranched; R2+3 and $\mathrm{R} 4+5$ longer than the vein $\mathrm{Rs} ; \mathrm{Cu}$ vein angled in the middle; Rs-M fused at a distance. Legs: hind coxa with Pearman's organ larger than the tympanum; trochanters with two long setae on the dorsum; ctenidiobothria present in fore tarsomeres, absent in mid- and hind- tarsomeres. Hypandrium (Fig. 5) (in paratypes) short and laterally widened, with dense field of long setae. Phallosome (Fig. 6) open basally; side rods straight, shorts; aedeagal arch robust, posterior process quadrangular, robust; external parameres absent; endophallus (radula) divided into two symmetrical areas, each with pointed spines directed antero-mesally and dense field of shorter spines and spicules latero-posteriorly. Paraprocts (Fig. 4) ovoid, posterior edged redounded, with setae, sensorial field with 29-32 trichobothria on basal rosettes. Epiproct (Fig. 4) broad basally, posterior margin broadly rounded, with microsetae and setae; mesal field with setae.

Measurements (in $\boldsymbol{\mu m}$ ). FW: 3225, HW: 2450, F: 725, T: 1200, t1: 480, t2: 180, ctt1: 18, f1: 400, Mx4: 190, IO: 460, D: 220, d: 180, IO/D: 2.56, PO: 0.81 .

Type locality. Colombia, Vaupés, Mosiro-Itajura, Antigua cabaña, 14'S, 69³'W, 60m., 17.VI.2000, IAvH. M. Sharkey \& D. Arias, in malaise trap. Holotype male. Paratypes: 1 male. Colombia, Amazonas, Leticia. Amacayacu, Mocagua, $1^{\circ} 4^{\prime} \mathrm{S}, 7^{\circ} 15^{\prime} \mathrm{W}, 150 \mathrm{~m}$. 9-12.III.2000, IAvH. M. Sharter \& B. Brown, in malaise trap. 1 male. Colombia, Amazonas, Amacayacu, Cabaña Lorena. $3^{\circ} 0 ’ \mathrm{~S}, 6^{\circ} 59^{\prime} \mathrm{W}$, $210 \mathrm{~m}$. In malaise trap. IAvH. 1 male.

Etymology. This species is dedicated to Dr. Alfonso Neri Garcia Aldrete, in recognition to his excellent and great contributions to the taxonomy of psocids.

\section{NEW RECORDS}

Neurostigma xanthopterum New, 1980: 194

2 males. COLOMBIA, Vaupés, Mosiro-Itajura, Centro ambiental, 1²'S: 69³1'W, 60m., 1-20.I-II.2003. M. Sharkey \& D. Arias, in malaise trap. This species was known only to Brazil (Table 1).

Table 1. Species of Neurostigma and known distribution.

\begin{tabular}{ll}
\hline SPECIES & DISTRIBUTION \\
\hline N. chaetocephallum Enderlein, 1901 & Peru \\
N. dispositum Roesler, 1940 & Brazil, Mexico, Peru \\
N. enderleini New, 1980 & Brazil \\
N. furcivenula Badonnel, 1986 & Colombia \\
N. garcialdretei n. sp. & Colombia \\
N. pausivenosum New, 1980 & Brazil \\
N. radiatum Mockford, 1991 & Brazil \\
N. roesleri New, 1980 & Brazil \\
N. xanthopterum New, 1980 & Brazil, Colombia. \\
\hline
\end{tabular}


KEY TO SPECIES (MALES) OF NEUROSTIGMA

N. furcivenula Badonnel, 1986 and $N$. roesleri New, 1980, are not included because only females are known.

N. chaetocephallum Enderlein, 1901, is not included because its genitalia (male) is unknown.

1. Areola postica fused to vein M; (Fig. 7 and 10); distal process of the aedeagal arch is very wide, trapezoidal (Fig. 9); pterostigma with seven or more crossvein (Fig.

7) .............................................................. 2

1'. Areola postica free, no fused to vein M (Fig. 1); distal process of the aedeagal arch often narrow or short (Fig. 6), pterostigma with two or until seven crossvein ...... 3

2. Endophallus (radular sclerites) with small denticles, more pronounced in midline (Fig. 9); vertex narrowed, raised and distinctly emarginate medially (Fig. 8); proximal half of forewing yellowish to brown, with large dark brown spots and hyaline basal area (Fig. 7), basal pterostigmal crossveins pigmented to the margin of the wing ........................... N. xanthopterum New, 1980

2'. Endophallus (radular sclerites) weakly developed; vertex not as above; proximal half of forewing dark brown; basal pterostigmal crossveins not being pigmented to the wing margin (Fig. 10) ..... N. enderleini New, 1980

3. Distal process of aedeagal arch somewhat wide, short, broadly rounded apically; forewing with cell $\mathrm{r} 3$ strongly sinuous ...................... N. dispositum Roesler, 1940

3'. Distal process of aedeagal arch narrow, elongated and rounded apically, or relatively robust and somewhat truncated apically; forewing with cell $\mathrm{r} 3$ not sinuous or somewhat sinuous .. 4

4. Pterostigma with two-three crossvein; phallosome with elongate and rounded apically distal process, radular sclerites with rows of sclerotized denticles

N. pausivenosum New, 1980

4'. Pterostigma with five to seven crossvein (Fig. 1), radular sclerite with spicules and large spines (Fig. 6) ..... 5

5. Radular sclerite with two long pointed spines directed anterolaterally, arising from dense field of shorter spines and spinulose membrane; aedeagal arc with angled apical inner edge; R4+5 $>3.0$ the length of Rs after the transverse vein $\mathrm{r}-\mathrm{m}$......... N. radiatum Mockford, 1991

5'. Radular sclerite with pointed spines directed antero-mesally, long spicules on external margin and dense field of short spines and spicules latero-posteriorly (Fig. 6); aedeagal arc with internal apical edge not angled; R4+5 $<2.5$ the length of Rs after the transverse vein $\mathrm{r}-\mathrm{m}$........ $N$. garcialdretei $\mathbf{n .} \mathbf{s p}$.

\section{DISCUSSION}

The species of the genus Neurostigma are difficult to find and problems arise when trying to establish phylogenetic relationships, due to the incomplete nature of some of their descriptions. On the other hand, females are very similar between species, differentiated mainly by the wings coloration pattern and a few characters of their external genitalia.

Based on the shape of the areola postica, two groups can now be distinguished within Neurostigma. The first group presents the areola postica fused to vein $\mathrm{M}$; it includes the species $N$. enderleini, $N$. xanthopterum and $N$. chaetocephallum. The first two are very similar to each other, differing mainly by the color tones in the body and wings, being darker in N. enderleini (New 1980). The radular esclerite in both species is very similar and somewhat difficult to contrast. The third species, $N$. chaetocephallum, presents difficulties when comparing with the other two species of the group, due to his short description, lack of knowledge of his genitalia and similarities in body coloration.

The second group, consisting of the six-remaining species: $N$. furcivenula, $N$. roesleri, $N$. dispositum, $N$. pausivenosum, $N$. radiatum and $N$. garcialdretei $\mathrm{n}$. sp., characterized by having the areola postica non-fused to the vein $\mathrm{M}$. In $N$. furcivenula and $N$. roesleri only females are known, these are very similar, differentiating them mainly by the shape and number of teeth of the lacinial apex and the posterior margin of the areola postica. Of the remaining four species, $N$. pausivenosum is the only one that has a pterostigma with only 2 crossveins, the others have five or more. Due to the shape of the phallosome, $N$. dispositum is clearly different of $N$. garcialdretei $\mathrm{n}$. sp. and $N$. radiatum. The last are differentiated by the shape and structure of their radula and the internal apical edge of the aedeagal arc (see identification key). Other secondary characteristics can be seen in the forewing coloration pattern and in the general shape of the areola postica.

With this new species, Colombia goes from a single registered species to having three (Table 1), which despite being a low number, corresponds to $33.33 \%$ of the known species of the genus. However, from the review of new collections in other natural areas, about five additional morphotypes have been identified and will be described in the future.

\section{ACKNOWLEDGMENTS}

We wish to thank the Departamento de Biología, Facultad de Ciencias Naturales y Exactas and Vicerrectoría de Investigaciones, Universidad del Valle, Santiago de Cali, Colombia, for their research support. We also thank Claudia Alejandra Medina, of the Alexander von Humboldt Institute for providing access to the Psocoptera Collections.

\section{LITERATURE CITED}

Badonnel, A. 1986. Psocoptères de Colombie (Insecta, Psocoptera). Spixiana 9 (2): 179-223.

Casasola-González, J. A. 2006. Phylogenetic relationships of the genera of Epipsocetae (Psocoptera: Psocomorpha). Zootaxa 1194 (1): 1-32.

Enderlein, G. 1901. Die Psocidenfauna Perus. Zoologischer Jahrbücher. Abtheilung für Systematik, Geographie und Biologie der Thiere, 14 (2): 133-160. 
Eertmoed, G. E. 1973. The phenetic relationships of the Epipsocetae (Psocoptera): the higher taxa and the species of two new families. Transactions of the American Entomological Society 99 (3): 373-414.

González, R., A. N. García Aldrete, and N. Carrejo. 2011. A new species of Steleops Enderlein, and a Colombian record of S. pulcher New (Psocodea: 'Psocoptera': Psocidae). Zootaxa 2735 (1): 23-27.

Recibido: 17 febrero 2020

Aceptado: 14 mayo 2020
Mockford, E. L. 1991. New species and records of Psocoptera (Insecta) from Roraima state, Brazil. Acta Amazonica, 21 (21): 211-318

Mockford, E. L. 1998. Generic definitions and species assignments in the family Epipsocidae (Psocoptera). Insecta Mundi 12 (1-2): 81-91.

New, T. R. 1980. Epipsocetae (Psocoptera) from the Reserva Ducke, Amazonas. Acta Amazonica, 10 (1): 179-206.

Roesler, R. 1940. Neue und wenig bekannte Copeognathengattungen. I. Zoologischer Anzeiger, 129 (9-10): 225-243.

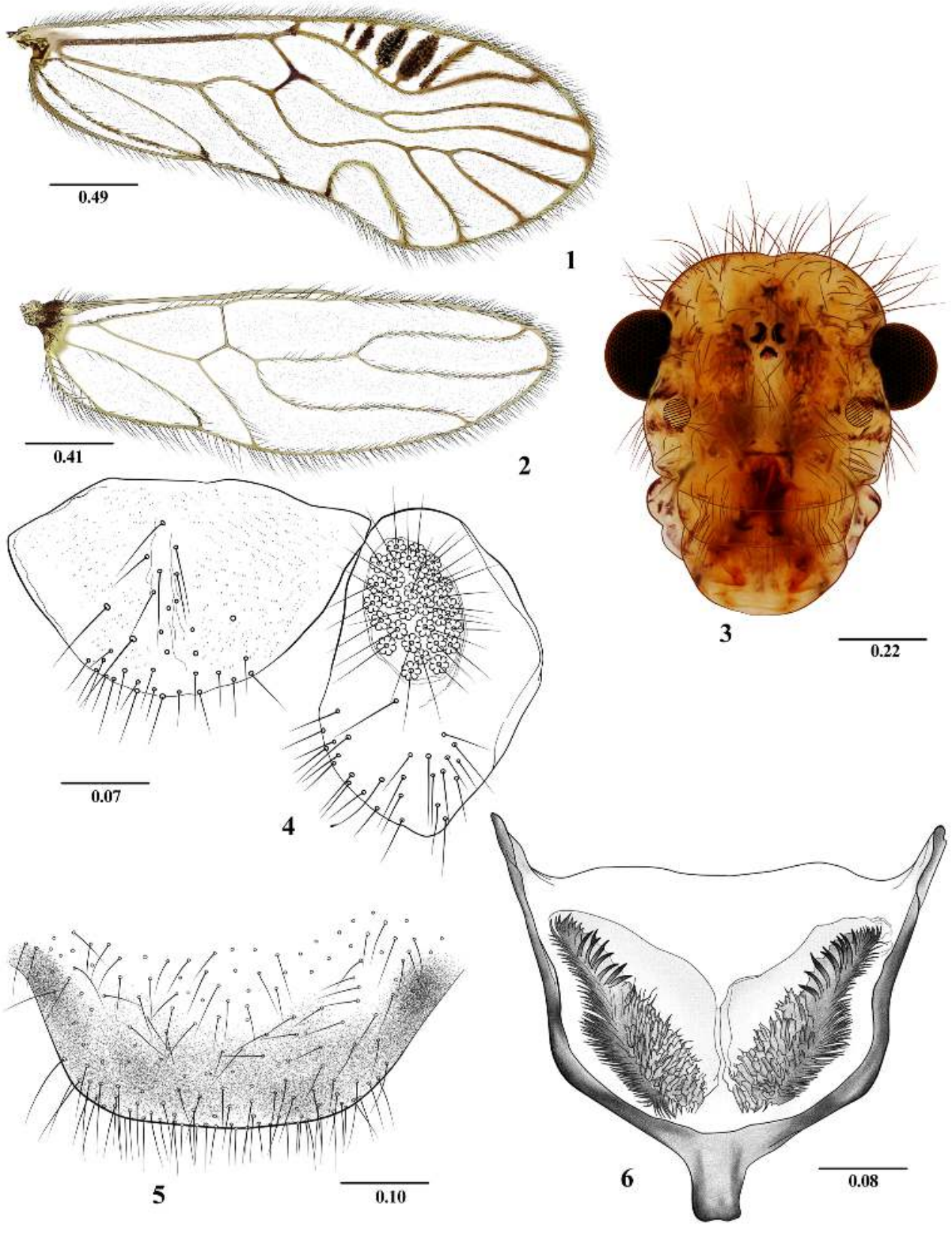

Figures 1-6. Neurostigma garcialdretei n. sp. Male. 1. Forewing. 2. Hindwing. 3. Front view of head. 4. Right paraproct and epiproct. 5. Hypandrium. 6. Phallosome. Scales in $\mathrm{mm}$. 

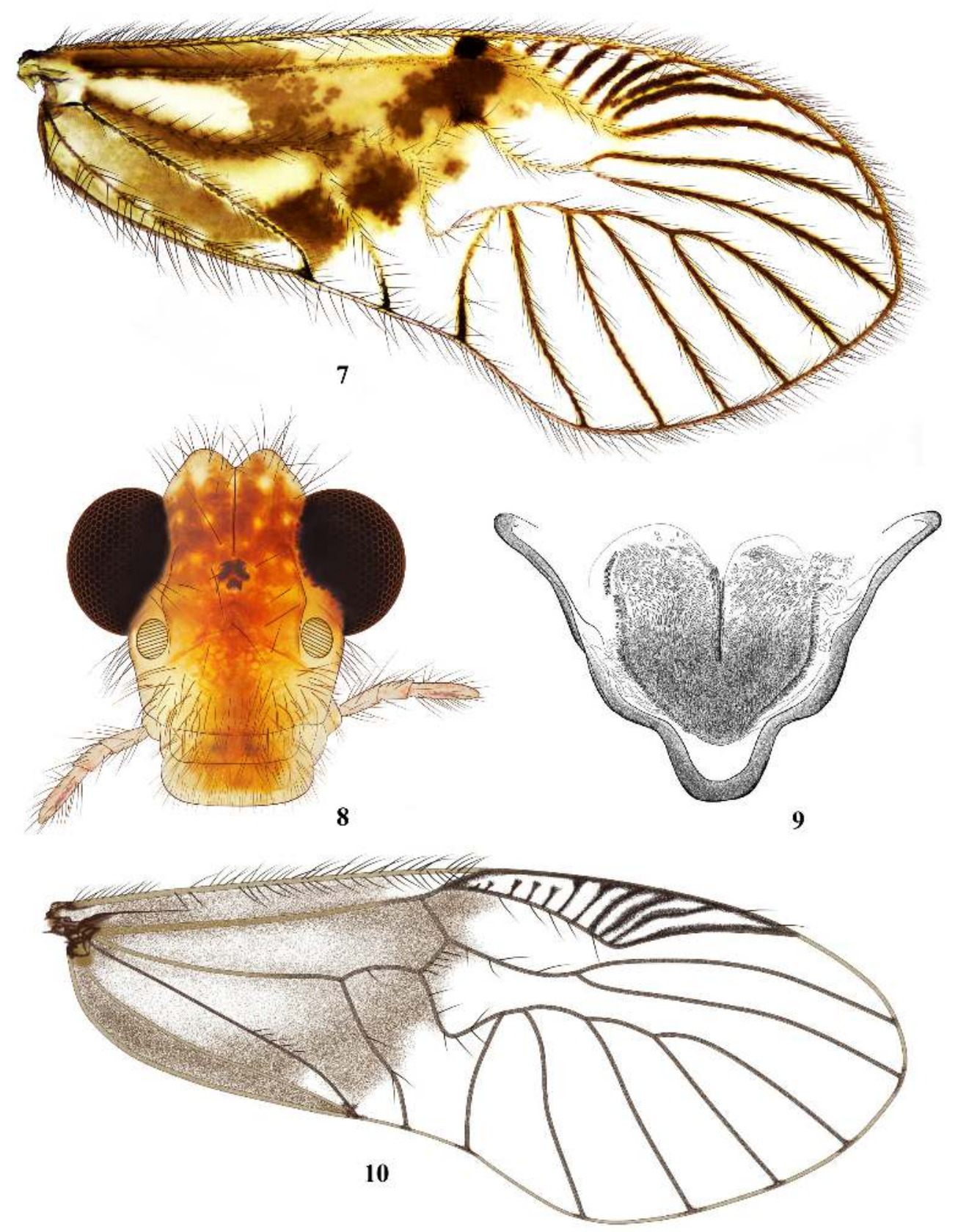

FIGURES 7-10. Neurostigma species. 7-9. N. xanthopterum. Male. 7. Forewing. 8. Front view of head. 9. Phallosome. 10. Forewing of N. enderleini, redrawn based on New original (New, 1980: Fig. 48). 